\title{
Response of a Freshwater Fish Exposed to a Single Dose of Biofertilizer
}

\author{
Nath $\mathrm{S}^{1 *}$ and Sardar $\mathrm{A}^{2}$ \\ ${ }^{1}$ Department of Zoology, Government General Degree College Singur, India \\ ${ }^{2}$ Department of Zoology, Bidhannagar College, India
}

*Corresponding author: Susanta Nath, Department of Zoology, Government General Degree College Singur (Affiliated to University of Burdwan), WB, Pin: 712409, India, Tel: +913326300126; Email: susanta_nath@yahoo.com

\section{Research Article}

Volume 3 Issue 1

Received Date: January 28, 2020

Published Date: February 10, 2020

DOI: $10.23880 /$ izab- 16000205

\section{Abstract}

The study was carried out to observe the effect of this biofertilizer (MOC) on the Body Muscle Protein (BMP) of Channa punctatus having average length $15.26 \pm 0.52 \mathrm{~cm}$ and weight $28.85 \pm 5.028 \mathrm{gm}$. At sub lethal concentration $\left(0.42 \mathrm{~g} . \mathrm{l}^{-1}\right)$, fishes were exposed for prolonged period and muscle protein was measured on $0,7^{\text {th }}, 14^{\text {th }}, 21^{\text {th }}$ and $28^{\text {th }}$ days respectively. Five fishes were sacrificed after each day of exposure to estimate the amount of protein concentration in the muscle following Folin-phenol reagent method. A significant $(\mathrm{p}<0.05)$ increase in BMP was observed with the advance of days treatment. After an initial fall, the rise in the BMP concentration, indicating the experimental fish were suffered initially and ultimately victorious and able to increase the protein level in their body.

Keywords: Mustard Oil Cake; Channa Punctatus; Body Muscle; Protein

\section{Introduction}

India and many other countries use organic fertilizers in aquaculture to augment the productive nature of a pond and also use as locally available food as rich source of protein [1]. In spite of the fact, use of right amount of organic fertilizer like, mustard oil cake along with rich bran, kitchen leftover etc.. during aquaculture can increase the production of fishes due to its protein richness [2]. Rohu fingerlings showed noticeable increase in growth and protein efficiency ratio when treated with fermented oil cake [3].

Proteins are very important structural molecules which undertook very important roles in various body functions whether it is enzymatic or non-enzymatic in nature and maintaining the metabolic harmony in the body. The change in the proximate component like protein might change the metabolic activity of fish, which alter the food value of the fish [4].

It is seen that the presence of less concentration of urea in the water can have toxic effects towards fishes and can significantly alter the electrophoretic pattern of proteins of different organs [5]. In a study, the detergent treated Catla catla shows low level of protein [6].

Decrease in the level of plasma globulin in fish exposed to toxicant might indicate the obstruction in hepatic protein synthesis as was observed in Cyprinus carpio [7]. Study also revealed that alachlor, a herbicide brings about considerable decrease in the muscle protein of the fish, and consuming muscle protein as energy source decreases productivity even mortality is absent [8].

Since fish are rich sources of proteins and lipids, their health is very important for human. Dominant species in an area 
are most important indicators as they receive the full impact of the habitat for over longer periods.

Fish are the rich source of lipid and protein and in most cases a staple food of human. Thus any effect of xenobiotics on fishes, may affect the human and also the aquatic habitats where the fishes are available [9]. Kannathasan, et al. [10] studied the comparative haematological parameters on Channa punctatus in reference to physiological stress. Ahmed, et al. [11] studied the effect of industrial wastes discharge on the physiological parameter of Tilapia nitoticus. Maitra, et al. [12] studied the impact of urea on the haematological parameter of Heteropnustus and revealed the recovery pattern from the effect of this organic fertilizer. Mustard oil cake has also significant effect on the liver protein of Channa punctatus [13]. These toxic chemicals after reaching sufficiently high concentration in the water bodies may cause damage to the ecosystem and also the physiological function of that aquatic organism [14]. So far no such study was done properly which can explore the effect of mustard oil cake on physiological aspect like body muscle protein of fish. The objective of the present experiment was to observe the effect of mustard oil cake on the muscle protein of Channa punctatus during various days of exposure.

\section{Materials and Methods}

\section{Selection of Species}

For the present study, Channa punctatus (Bloch) was selected by considering its economic value and availability of this fish in the market almost throughout the year. The fish were procured from nearest market of Saltlake, Kolkata, having average length $15.26 \pm 0.52 \mathrm{~cm}$ and weight $28.85 \pm 5.028 \mathrm{gm}$. Infected and disease fish were avoided.

\section{Rearing \& Culture}

After disinfecting with $1 \% \mathrm{KMnO}_{4}$ solution; fish were kept in glass aquarium provided with dechlorinated tap water at laboratory conditions. Experimental fishes were transferred into aquarium $(90 \mathrm{~cm} \times 50 \mathrm{~cm} \times 31 \mathrm{~cm})$ containing the solution of mustard cake powder was added $0.42 \mathrm{~g} . \mathrm{l}^{-1}$ of water. Each aquarium contains 48 liters of water. Commercial fish food (containing crud protein $46 \%$, fat $6 \%$ and fiber 5\%) was provided during acclimatization as well as treatment period at the rate of $5 \%$ of the fish body weight, once a day.

\section{Bio-Fertilizer Used}

Mustard oil cake powder was considered for the experiment because of its regular use as supplementary fish food by the farmer in West Bengal.

The chemical composition of MOC is: $43 \%$ protein, $2.05 \%$ oil, $1.22 \%$ Allylisothiocyanate (AITC) and 2.75\% phytic acid. Phytic acid usually regarded as an anti-nutritive factor [15].

\section{Treatment}

Five aquaria were maintained at the same time for the experiment provided with ten fish in each aquarium treated with $0.42 \mathrm{~g} . \mathrm{l}^{-1}$ of mustard cake powder and control also maintained in the similar way without treatments. $\mathrm{LC}_{50}$ was calculated by using the method of Finney [16]. Mortality was recorded for $96 \mathrm{hrs}$ by using 10 fish for various concentrations and $\mathrm{LC}_{50}$ was estimated during the experiment.

Groups of fishes exposed in $0.42 \mathrm{~g} . \mathrm{l}^{-1}$ sub lethal concentration of Mustard oil cake powder as this concentration was below the value of $\mathrm{LC}_{50}$ [17]. Five fishes were sacrificed after each day of exposure. One more set of fishes were maintained as control. The physiochemical properties of the water were: alkalinity $293+1.4$, Dissolve Oxygen $8.5+2.0 \mathrm{mg}^{-1}{ }^{-1}$, temperature of water $25 \pm 0.4^{\circ} \mathrm{C}, \mathrm{pH}$ $7 \pm 0.2$ recorded for the test water [18].

The fishes were sacrificed at the end of tested exposure period and body muscle was processed for further study. Fishes were sacrificed for each day of exposure to estimate the amount of protein Concentration in the muscle following Folin-phenol reagent method [19].

\section{Statistical Analysis}

Statistical analyses were done by using origin 6.0 software. Correlation coefficient (R) was calculated and result was compared with $\mathrm{t}$-value. Linear regression line was presented on the basis of the available data. Oneway ANOVA was calculated and strength of Association $\left(\omega^{2}\right)$ was measured [20,21].

\section{Results and Discussion}

The toxicity of the mustard oil cake was measured on Channa punctatus and concentration of body muscle protein (BMP) was estimated during the study. The present experiment revealed that at $0.42 \mathrm{~g} . \mathrm{l}^{-1}$ of MOC no abnormal mortality has been observed after prolonged period of exposure but fish were at physiological stress on initial days.

In 0 day control BMP was found to $12.7 \pm 0.28 \mathrm{mg} . \mathrm{g}-1$ whereas different result was obtained in control between 7 th day and 28thday (Table 1). In treated fish the level of BMP were $25.59 \pm 0.2 \mathrm{mg}$.g-1 (EP-7 days), $23.42 \pm 0.55 \mathrm{mg} . \mathrm{g}-1$ (EP14 days), $46.14 \pm 0.46$ mg.g-1 (EP-21 days) and 58.53 \pm 2.79 mg.g-1 (EP-28 days). A significant $(\mathrm{P}<0.05)$ increase in BMP was obtained with the advance of days of exposure. Study also revealed a significant relation between exposure period and amount of BMP when one-way ANOVA was done 


\section{International Journal of Zoology and Animal Biology}

$(\mathrm{F}=4.75, \mathrm{P}<0.05)$.Strength of association $(\omega 2)$ was measured to estimate the degree of relatedness between duration of exposure and the amount of BMP the computed values showed the proportion as $99(99 \%)[\mathrm{EP}=14]>0.89(89 \%)$ $[\mathrm{EP}=7]>0.81(81 \%)[\mathrm{EP}=35]>0.30(30 \%)[\mathrm{EP}=28]>$ $0.034(3.4 \%)[\mathrm{EP}=21]$ of total variance of protein level was related to the duration of the exposure.

Correlation coefficient $(R)$ was $0.95(t=5.39, p<0.05$ and $\mathrm{Y}=27.66+0.758 \mathrm{x})$ and $0.93(\mathrm{t}=4.38, \mathrm{p}<0.05, \mathrm{Y}=8.035+1.736 \mathrm{x})$ and regression is presented in Figures $1 \& 2$ for control and treated fishes respectively.

\begin{tabular}{|c|c|c|c|c|c|}
\hline \multirow{2}{*}{ Type of Specimen } & \multicolumn{5}{|c|}{ Muscle proteins mg g $^{-1}$ (mean SE) } \\
\hline & O DAYS & 7 DAYS & 14 DAYS & 21 DAYS & 28 DAYS \\
\hline Control (Non-Treated) & \multirow{2}{*}{$12.7 \pm 0.28$} & $31.08 \pm 4.21$ & $40.15 \pm 0.4$ & $45.52 \pm 0.71$ & $46.99 \pm 1.49$ \\
\hline Treated & & $25.59 \pm 0.2$ & $23.42 \pm 0.55$ & $46.14 \pm 0.46$ & $58.53 \pm 2.79$ \\
\hline \multicolumn{2}{|c|}{ Strength of Association $\left(\omega^{2}\right)$} & & 0.99 & 0.034 & 0.3 \\
\hline
\end{tabular}

Table 1: Amounts of muscle proteins $\left(\mathrm{mg} \mathrm{gm}^{-1}\right)$ in treated and non-treated Channa punctatus (five fishes for each day of exposure).

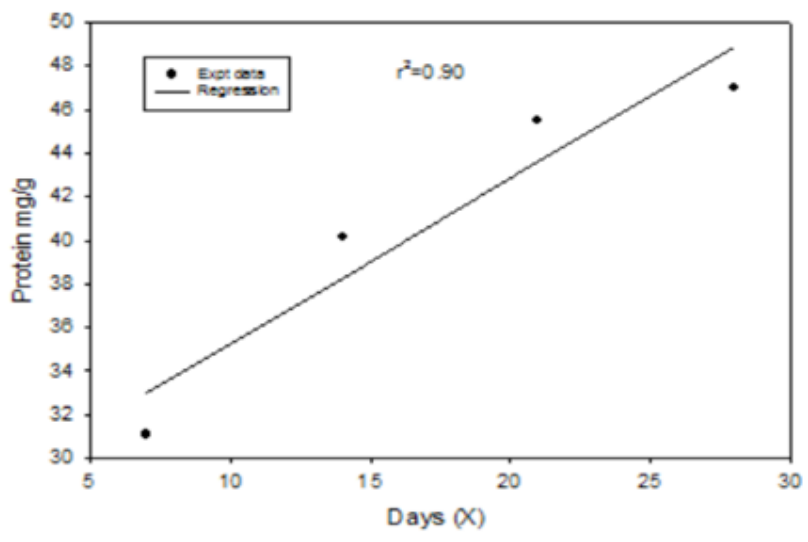

Figure 1: Representing the regression between days of exposure and muscle protein of control (non-treated) fish.

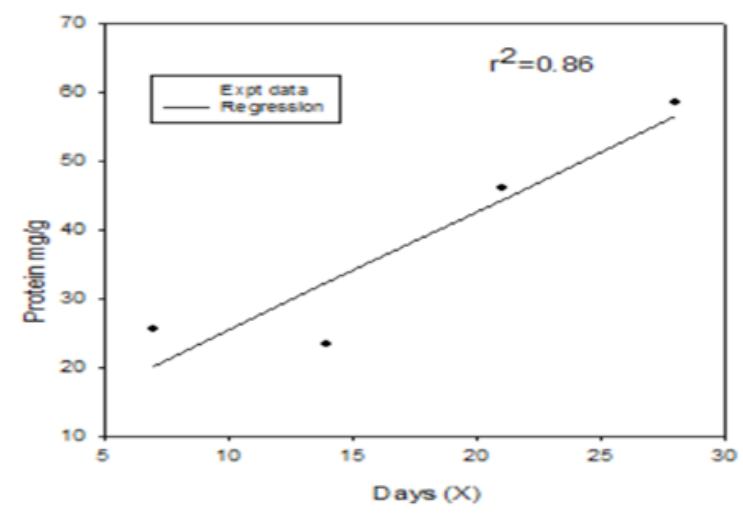

Figure 2: Representing the regression between days of exposure and muscle protein of treated fish.
Impact of Mustard oil cake on the BMP revealed that protein concentration after 7 days of treatment was significantly higher than the control. In the living organisms protein is an important constituent of all the cells and tissues and plays an important role in physiological activities as well as a source of energy during the period of stress $[22,23]$. Between 21 and 28 days there was rapid increase in protein concentration maintained a study state which was higher than $14^{\text {th }}$ day as well as controlled. This might indicated the fish competence to cope up with adverse stress situation. This is reason that more protein was used to meet the increase in energy demand, which led to increase the rate of protein synthesis. During the experiment culture medium was contaminated with MOC contains $43 \%$ protein and it is also a rich source of nitrogen $[15,24]$.

In a separate study average weight gain of fish was obtained when the pond was treated with urea [25], whereas, Tarar, et al. [26] obtained higher net fish production from a pond which was urea treated as a source of non-protein nitrogen and better nitrogen incorporation efficiency. As a rich source of protein in MOC used during the present experiment, it was probable that increase in protein synthesis was accelerated by the consumption of protein and nitrogen from the culture medium by the fish. Protein is the chief source of nitrogen metabolism and protein concentration showed gradual increase during the long term exposure. During the long term exposure, an increase in the muscle protein concentration was observed. The rate of protein synthesis or its degradation regulates the quantity of protein.

When animals were exposed to stress, the survival ability mainly depends on their protein synthetic potential [27]. There significant decrease in muscle protein after 7 and 14 days exposure relative to controls. Such degradation advocates the increase in proteolytic activity and reasonable utilization of these products for metabolic purposes [28- 
30]. Moreover, such fallen protein level in exposed fish was probably due to increase catabolism and decreased anabolism of protein [17,31]. During day 21 and 28 there was a rapid increase in muscle protein. That increment was less on 21 day because almost same amount of protein was recorded in control on the same day. That was also observed in toxic metal affected Mugil seheli [32]. In general, fish could respond to various stress as by series of biochemical and physiological stress reactions, known as secondary stress responses in compare to higher vertebrates [33].

Such increase in protein level after 21 and 28 day might be due to the induction of microsomal enzymes for detoxification of materials of external origin and other constituent enzymes of various metabolic process [34,35]. As a result, organs were developing resistance against stress and also initiate the synthesis of enzymes necessary for detoxification. Catabolism of proteins may provide energy to fish and as main constituent of cell, it is the chief source of nitrogen metabolism [36,37]. From the present study it is appeared that the experimental fish were suffered initially and ultimately victorious and able to increase the protein level in their body.

\section{Conclusion}

Channa punctatus (Bloch) was exposed to $0.42 \mathrm{~g} . \mathrm{l}^{-1}$ of MOC treated water for prolonged 28 days of exposure. With the initial decrease in protein level at $7^{\text {th }}$ day, muscle protein was found to increase with the advancement of exposure period and show highest muscle protein level at $28^{\text {th }}$ day in both treated and control (non-treated) fishes. Study revealed that MOC was an effective biofertilizer to increase the protein concentration in the muscle of fish.

\section{Acknowledgement}

Authors are thankful to the Principal, Bidhannagar College and Dr. Shekhar Mukherjee former HOD, Post Graduate Department of Zoology of the same college for providing laboratory facilities during this work. Dr. Susanta Nath was posted in the above mentioned college during this work. Authors are also gratefully acknowledged Dr. Shrijit Bhattacharjee, Assistant Professor of Physics, Barasat Govt College for helping in statistical analyses.

\section{References}

1. Singh R, Singh P, Nayak SK, Reang D, Tripathi G (2017) To study the acceptability of different feed ingredients like, rice bran, fish meal, mustard oil cake and floating feed in earthen pond fed via Tor tor (Hamilton, 1822) fingerlings. Int J Fish Aquat Stud 5(5): 135-139.

2. Bhandari S, Kaphle S, Lams RK (2019) Local feeds in aquaculture and their feeding efficiency: Review from Nepal. International J Vet Sc Ani Husbandry 4(5): 6-9.

3. Ghosh K, Mandal S (2015) Nutritional evaluation of groundnut oil cake in formulated diets for rohu, Labeo rohita (Hamilton) fingerlings after solid state fermentation with a tannase producing yeast, Pichia kudriavzevii (GU939629) isolated from fish gut. Aquacul Rep 2: 82-90.

4. Naqvi GZ, Shoaib N, Ali MA (2017) Pesticides impact on protein in fish (Oreochromis mossambicus) tissues. Indian J Mar Sci 46(9): 1864-1868.

5. Salahudeen SMB, Muthukumaravel K, Kumarasamy $P$ (2014) Impact Of Nitrate Fertilizer Urea On The Electrophoretic Protein Pattern of Different Organs In The Freshwater Fish Oreochromis mossambicus. Int J Recent Sci Res 5(1): 133-135.

6. Priya R, Loganathan S, Ganapathi N, Jothi Narendiran N (2014) Estimation Of Protein In The Detergent Induced Toxicity Fish, Catla catla. J Global Biosciences 3(1): 314320.

7. Ghelichpour M, Mirghead AT, Mirjargar SS, Joshaghani H, Mousavi HE (2017) Plasma proteins, hepatic enzymes, thyroid hormones and liver histopathology of Cyprinus carpio (Linnaeus, 1758) exposed to an oxadiazin pesticide, indoxacarb. Aquac Res 48(11): 5666-5676.

8. Tilak KS, Wilson Raju P, Butchiram MS (2009) Effects of alachlor on biochemical parameters of the freshwater fish ,Channa punctatus (Bloch). J Environ Biol 30(3): 421-426.

9. Srivastava P, Singh A, Pandey AK (2016) Pesticides toxicity in fishes: Biochemical, Physiological and Genotoxic Aspects. Biochem Cell Arch 16(2): 199-218.

10. Kannathasan MK, Rajendran K (2012) Comparative haematological studies on fresh water fishes Channa punctatus and Channa striatus(Bloch). Int J Pharm Chem Biol Sci 2(4): 644-648.

11. Ahmed DFI (2013) Effect of industrial waste discharge including heavy metals Burullus lake on some physiological parameters and anti-oxidants in Tilapia niloticas and Siluriformes fish. N Y Sc J 6(4): 85-92.

12. Maitra S, Nath S (2014) Toxic impact of urea on the Heteropnustes fossilis (Bloch). Am Eurasian J Agric Environ Sci 14(4): 336-334.

13. Nath S, Rakshit P, Matozzo V (2018) Effects of mustard oil cake on liver proteins of Channa punctstus (Bloch). Interdiscip Toxicol 11(2): 200-203. 
14. Javed M, Usmani N (2019) An overview of the adverse effects of heavy metal contamination on fish health. Proc Natl Acad Sci India Sect B Biol Sci 89(2): 389-403.

15. Khan Niazi AH (1986) Improvement in the Nutritive Value of Mustard seed Cake Doctoral thesis, University of Punjab, Lahor, Pakisthan, pp: 13-14.

16. Finney DJ (1978) Probit Analysis. 3rd (Edn.), Griffin Press London: Cambridge University Press, London, UK, pp: 508.

17. Binukumari S, Vasanti J (2013) The Toxic Effect of Pesticide Dimethoate 30\% EC on the protein Metabolism of the Freshwater Fish Labeo rohita. Int J Curr Microbiol Appl Sci 2(12): 79-82.

18. APHA (1998) Standard Methods for the Examination of Water and Waste water. American Public Health Association, Washington, DC.

19. Lowry OH, Rosenbrough NJ, Farr AL, Randall RJ (1951) Protein measurement with Folin phenol reagent. J Biol Chem 193(1): 265-275.

20. Zar JH (2009) Biostatistical Analysis. 4th (Edn.), Pearson Education, New Delhi, India, pp: 177-185.

21. Das D, Das A (2010) Statistics in Biology and Psychology. 6th (Edn.), Academic Publishers, Kolkata, India, pp: 147.

22. Adamu KM, Siakpere OK (2011) Effect of Sub lethal Concentration of Tobacco (Nicotina tobaccum) Leaf Dose on Some Biochemical Parameters of Hybrid Catfish (Clarius garipines and Heterobranchus bidorsalis). Brazil Arch Biol Tech 54(1): 183-196.

23. Umminger BL (1977) Relation of whole blood sugar concentration in vertebrate to standard metabolic rate. Comp Biochem Physiol 56(4): 457-460.

24. Mondal S, Das R, Das AC (2014) A comparative study on the decomposition of edible and non-edible oil cake in Gangetic alluvial soil of West Bengal. Environ Monitor Asses 186(8): 5199-5207.

25. Abbas S, Ahmed I, Akhtar P, Asghar T (2001) Response of Urea on the growth performance of major carp viz., Labeo rohita, Catla catla and Cirrhinus mrigala. Pak Vet J 21(4): 211-213.

26. Tarar SR (1997) Comparison of fish length and weight based doses of inorganic fertilizer in pond fisheries. M.Sc.
Thesis, Department of Zoology and Fisheries University of Agriculture Faisalabad, Pakistan, pp: 78.

27. Rohankar P, Zade V, Dabhadkar D, Lebhsetwar N (2012) Evaluation of Impact of phosphamidon on Protein Status of Freshwater Fish Channa punctatus. Indian J Sci Res 3(1): 123-126.

28. Mastan SA, Rammayya PJ (2010) Biochemical profile of Channa gachua(Ham)exposed to sublethal doses of Dichlorovas(DDVP). The Internet J Toxicol 8(1): 27-32.

29. Palanichamy S, Arunachalam A, Baskaran P (1989) Effect of pesticides on protein metabolism in the freshwater catfish Mystus vittatus. J Ecobiol 1: 90-97.

30. Ghosh D, Dutta S, Bhattacharya S, Mazumder S (2006) Perturbations in the catfish Immune Response by Arsenic: Organ and cell specific effects. Com Biochem Physiol 143(4): 455-463.

31. Ganeshwade RM (2012) Biochemical changes induced by Dimethoate (Rogor 30\% EC) in the gills of freshwater fish Pinctius ticto (Hamilton). J Ecol Nat Environ 4(7): 181-185.

32. Abou El-Naga EH, El-Mosehy KM, Hanmed MA (2005) Toxicity of cadmium and copper and their effect on some biochemical parametersof marine fish Mugil sheheli. Egypt J Aquat Res 31(2): 60-71.

33. Mazeaud M, Mazeaud F (1981) Adrenergic responses to stress in fish. In: Pickring AD, et al. (Eds.), stress and Fish. Academic Press, New York and London, pp: 49-57.

34. Mukhopadhyay PK, Dehadri PV (1987) Metabolic fate of dietary non-protein nitrogen in Heteropnustes fossilis (Bloch). Ind J Fisheries 34(3): 237-244.

35. Singh AP, Singh S, Bhartiya P, Yadav K (2010) Toxic effect of phorate on the serum biochemical parameters of snake headed fish Channa punctatus (Bloch). Adv Biores 1(1): 177-181.

36. Krueger HM, Saddler JB, Chapman GA, Tinsley IJ, Lowry RR (1968) Bioenergetics, exercise and fatty acids of fish. Am Zool 8: 119.

37. Naveed A, Janaiah C, Venkateshwarlu P (2010) The effects of Lihocin toxicity on protein metabolism of the fresh water edible fish Channa punctatus (Bloch). J Toxicol Environ Health Sc 3(1): 18-23. 